\title{
Overweight and obesity of children in a brazilian elementary school: a comparison of three references
}

\author{
Marcella Evangelista Melo ${ }^{1}$, Giovanna Lima Miguéis ${ }^{2}$, Mikaela Silva Almeida ${ }^{2}$, Tatiane Dalamaria ${ }^{3}$, \\ Wagner de Jesus Pinto ${ }^{3}$, Margarida de Aquino Cunha ${ }^{3}$, Edson dos Santos Farias ${ }^{3}$, \\ Ítalla Maria Pinheiro Bezerra ${ }^{4}$, Orivaldo Florencio de Souza ${ }^{1,3}$
}

DOI: http://dx.doi.org/10.7322/jhgd.122817

\begin{abstract}
:
Introduction: In the diagnosis of overweight and obesity based on body mass index in children and adolescents, several national and international anthropometric references are recommended. However, there is a divergence in the estimated prevalence of overweight and obesity among the references.

Objective: To identify the prevalence of overweight and obesity and to analyse the magnitude of agreement among the three references.

Methods: A cross-sectional study with 975 students from the early grades of elementary school. The prevalence of overweight and obesity were estimated according to the criteria of the World Health Organization (WHO), the International Obesity Task Force (IOTF) and Conde and Monteiro. The Kappa weighted index was calculated to assess the agreement magnitude among the three references.

Results: The highest prevalence of overweight and obesity was estimated by the Conde and Monteiro and WHO references, respectively. Overall, the IOTF revealed lower a magnitude of prevalence than the two other references. The agreement among the references identified by the Kappa index had a range of 0.66 to 0.94 .

Conclusion: Despite the satisfactory agreement among the three references, this research highlighted the differing magnitudes of the prevalence of overweight and obesity. This fact limits the ability to make comparisons among populations and impairs the development of overweight and obesity prevention actions.
\end{abstract}

Keywords: prevalence, body mass index, anthropometry, overweight, obesity, students.

\section{INTRODUCTION}

Major changes in the nutritional profile of Brazilian children and adolescents have been characterised by the reduction in the prevalence of malnutrition and the increased prevalence of overweight and obesity ${ }^{1}$. Overweight and obesity are nutritional disorders that can begin at any age and present multifactorial features. In addition, there is evidence that overweight and obesity continue from childhood and adolescence into adulthood, raising the morbidity and mortality associated with overweight and decreasing life expectancy ${ }^{2,3}$.

The body mass index (BMI), because of its easy interpretation, fast measurement and low-cost, is widely used to monitor the overweight and obesity of children, adolescents and adults. In particular, for the diagnosis of overweight and obesity by BMI in children and adolescents, several benchmarks are recommended ${ }^{4-6}$.

In 2007, the World Health Organization (WHO) recommended the use of a new anthropometric standard for monitoring the growth and nutritional status of children aged above 5 years ${ }^{4}$. This new standard was established on the basis of samples from six countries with considerable ethnic and cultural variability. Another benchmark that is widely used in the estimation of overweight and obesity was drafted by Cole et al. ${ }^{5}$ with data from children and adolescents from six countries in the age group from 2 to 18 years, and it was subsequently recommended for worldwide use by the International Obesity Task Force (IOTF). In Brazil, Conde and Monteiro ${ }^{6}$ created a strictly

\footnotetext{
1 Acadêmica de Nutrição, Centro de Ciências da Saúde e dos Desportos, Universidade Federal do Acre.

2 Mestranda em Saúde Coletiva, Centro de Ciências da Saúde e dos Desportos, Universidade Federal do Acre.

3 Doutor em Saúde Pública, Centro de Ciências da Saúde e dos Desportos, Universidade Federal do Acre.

4 Programa de pós-graduação em ciências da saúde da amazônia ocidental, Universidade Federal do Acre. Corresponding author: Orivaldo Florencio de Souza - Email: orivaldofs.ufac@gmail.com
} 
Brazilian reference based on the anthropometric data of children and adolescents from 2 to 19 years of age from the national Health and Nutrition Survey of 1989.

Diverging estimates of the prevalence of overweight and obesity by the $\mathrm{WHO}^{4}$, the $\mathrm{IOTF}^{5}$ and Conde and Monteiro ${ }^{6}$ references were observed in Brazil and other countries ${ }^{7-11}$. This fact represents a challenge for public health in the recommendation of the appropriate benchmark for children's growth and the comparison of the prevalence of overweight and obesity among localities. Thus, the objective of this study is to verify the prevalence of overweight and obesity, and to review the magnitude of the correlation among the references of the WHO, the IOTF and Conde and Monteiro in a school in the municipality of Rio Branco, Acre, Brazil.

\section{METHODS}

This is a cross-sectional study with children from the early grades of elementary school in the urban area of the city of Rio Branco, Acre State, Brazil. To determine the minimum size of the sample, the expected prevalence of $35 \%$ was adopted, with the fixed precision of a sampling error of $3 \%$ at a $95 \%$ level of confidence. The minimum size of the sample was 971.

Conglomerate sampling was used in stages, where the primary units were the schools. Out of the total of 22 municipal urban area schools that offered the $1^{\text {st }}, 2^{\text {nd }}$ and $3^{\text {rd }}$ grades of elementary school, 5 (five) schools were drawn by simple random sampling to participate in the study. The number of schools was determined by the restrictions on the number of researchers and the time available for conducting the interviews. All students in the $1^{\text {st }}, 2^{\text {nd }}$ and $3^{\text {rd }}$ grades of elementary school from each school drawn were invited to participate in the data collection. The exclusion criterion was the presence of morbidities that precluded anthropometric measurement. The inclusion criterion was being regularly enrolled in and attending school. This project was approved by the Committee of Ethics in Research with
Human Beings (CAAE: 27915514.2.0000.5010) from the Universidade Federal do Acre.

For the measurement of weight, a portable electronic digital scale was used, which was accurate to 50 grams and had a maximum capacity of $150 \mathrm{~kg}$. Height was measured by a portable stadiometer with a precision of 0.1 $\mathrm{cm}$ and a maximum extension of 2 metres. The anthropometric measurements in children were taken during a class period, following the procedures recommended by Petroski $^{12}$.

The Z-scores of the body mass index (BMI) were obtained according to the WHO recommendations of $2007^{4}$, being classified as: obesity, $(>+2 \mathrm{Z}$ score), overweight ( $<+2$ and $>+1 \mathrm{Z}$ score) and eutrophic $(<+1$ $\mathrm{Z}$ score). Based on the benchmarks of BMI by gender and age of the IOTF$^{5}$ and Conde and Monteiro ${ }^{6}$, the categories of eutrophic (below $25 \mathrm{~kg} / \mathrm{m}^{2}$ ), overweight (25 $\mathrm{kg} / \mathrm{m}^{2}$ and $30 \mathrm{~kg} / \mathrm{m}^{2}$ ) and obesity (greater than $30 \mathrm{~kg} / \mathrm{m}^{2}$ ) were determined.

The data were regularly entered into the EpiData program. The statistical analysis was done with the Stata 12.0 program. The prevalence of overweight and obesity rankings was calculated by gender. The weighted Kappa index was calculated to assess the concordance between the three benchmarks $(\mathrm{p}<0.05)$ using the Stata 12.0 program.

\section{RESULTS}

The sample consisted of 975 students, aged 5 to 11 years, from the $1^{\text {st }}, 2^{\text {nd }}$ and $3^{\text {rd }}$ grades, from five elementary schools in Rio Branco, Acre, Brazil. Information was collected from 483 (49.54\%) males and 492 (50.46\%) females.

The highest prevalence of overweight and obesity was estimated by the Conde and Monteiro ${ }^{6}$ and $\mathrm{WHO}^{4}$ references, respectively (Table 1). The concordance between the anthropometric references identified by the Kappa index presented a range of 0.66 up to 0.94 . The smallest concordances occurred between the WHO reference ${ }^{4}$ vs

Table 1: Overweight and obesity prevalence in students from the early grades of public elementary schools in Rio Branco, Acre, Brazil, 2014

$\begin{array}{lccc} & \text { WHO } & \text { IOTF } & \text { Conde \& Monteiro } \\ \%\end{array}$


Conde and Monteiro ${ }^{6}($ Kappa $=0.66)$ and between $\mathrm{OMS}^{4}$

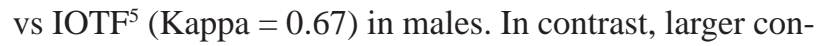
cordances were observed between the WHO reference ${ }^{4}$ vs
Conde and Monteiro ${ }^{6}($ Kappa $=0.94)$ in females and between $\mathrm{IOTF}^{5}$ vs Conde and Monteiro ${ }^{6}(\mathrm{Kappa}=0.90)$ in males (Table 2).

Table 2: Concordance among the references to overweight and obesity in the early grades of public elementary schools in Rio Branco, Acre, Brazil, 2014

\begin{tabular}{|c|c|c|c|}
\hline & $\begin{array}{c}\text { WHO vs } \\
\text { IOTF } \\
\text { Kappa (IC95\%) }\end{array}$ & $\begin{array}{c}\text { WHO vs } \\
\text { Conde \& Monteiro } \\
\text { Kappa (IC95\%) }\end{array}$ & $\begin{array}{c}\text { IOTF vs } \\
\text { Conde \& Monteiro } \\
\text { Kappa (IC95\%) }\end{array}$ \\
\hline $\begin{array}{l}\text { All } \\
\text { Male } \\
\text { Female }\end{array}$ & $\begin{array}{l}0,74(0,69 ; 0,79)^{*} \\
0,67(0,59 ; 0,75)^{\star} \\
0,81(0,74 ; 0,87)^{\star}\end{array}$ & $\begin{array}{l}0,81(0,76 ; 0,85)^{\star} \\
0,66(0,58 ; 0,74)^{\star} \\
0,94(0,91 ; 0,98)^{\star}\end{array}$ & $\begin{array}{l}0,84(0,80 ; 0,89)^{*} \\
0,90(0,85 ; 0,95)^{\star} \\
0,78(0,71 ; 0,85)^{\star}\end{array}$ \\
\hline
\end{tabular}

$* p<0,05$.

\section{DISCUSSION}

Substantial prevalence of overweight and obesity in schoolchildren was identified by the $\mathrm{WHO}^{4}$, the $\mathrm{IOTF}^{5}$ and the Conde and Monteiro ${ }^{6}$ references. In 2004, through the $\mathrm{WHO}^{4}$ frame, the prevalence of overweight and obesity in the early grades of public elementary schools in Rio Branco, Acre, Brazil, was 17.3\% in males and 17.8\% in females ${ }^{13}$. In contrast, the information about overweight students obtained this study, collected in 2014, showed an increase of $7 \%$ in males and $3 \%$ in females. This fact indicates that excess weight is an emerging problem in the schools investigated.

The estimates of the prevalence of overweight and obesity among the references were divergent, as the $\mathrm{WHO}^{4}$ frame showed a prevalence of overweight and obesity that was higher than that estimated by the IOTF reference ${ }^{5}$. This finding is similar to that identified in the children of Argentina ${ }^{9}$, Pakistan ${ }^{10}$, Canada ${ }^{11}$ and Brazil ${ }^{7,8}$. In contrast, in the Czech Republic ${ }^{14}$, children presented a prevalence of overweight that was greater than that estimated by the IOTF reference ${ }^{5}$.

According to studies carried out in southern Bra$\mathrm{zil}^{7,8}$, the Conde and Monteiro ${ }^{6}$ reference showed a greater estimate of the prevalence of overweight and obesity in comparison to the $\mathrm{WHO}^{4}$ and $\mathrm{IOTF}^{5}$ references. However, Pelegrini et al. ${ }^{15}$ identified a prevalence of overweight that approximated the $\mathrm{WHO}^{4}(20.1 \%)$ and $\operatorname{IOTF}^{5}$ (20.6\%) references; the $\mathrm{IOTF}^{5}$ consistently presented a prevalence below the other references. The fact that none of three references used in this investigation are considered gold standards in the diagnosis of overweight and obesity makes it impossible to deduce whether the $\mathrm{WHO}^{4}$ and Conde and Monteiro ${ }^{6}$ references overestimate or the $\mathrm{IOTF}^{5}$ underestimates the prevalence of overweight and obesity.

Similarities identified among the three references in all of the groups examined were classified as substantial or nearly perfect, according to the criteria of Landis and Koch ${ }^{16}$, with a Kappa value ranging between 0.66 and 0.94 . For the total sample, the largest alignment identified was between IOTF $^{5}$ vs Conde and Monteiro ${ }^{6}$.
This finding is inconsistent with Dumith and Farias Junior $^{7}$ and Pelegrini et al. ${ }^{15}$, in which the largest correlation was observed between the $\mathrm{WHO}^{4}$ and Conde and Monteiro ${ }^{6}$ references.

The differences in the estimates of overweight and obesity in the schools analysed in this study may be due to the different methods used by the three references in the preparation of growth curves and the arbitrary procedures for the proposition of the cut points. Moreover, the divergent characteristics of the samples that gave rise to the references could lead to uneven estimates of the prevalence of overweight and obesity.

The prevalence of overweight and obesity in each region and ethnic diversity can affect the reliability of the reference for growth ${ }^{11,18}$. However, all of the references used in this study included contributions from samples of Brazilian children and adolescents. Specifically, the Conde and Monteiro ${ }^{6}$ reference only used a sample of Brazilian children and adolescents from the north of the urban area. However, due to the lack of studies with confirming evidence of which reference reveals the real potential for the growth and development of children, the recommendation of Conde and Monteiro ${ }^{6}$ to estimate the prevalence of overweight and obesity in the schools of Rio Branco, Acre, Brazil is hindered.

One limitation of the present study was that it was performed only with public school students in the urban area who attended the school during the period of the data collection. On the data quality, the Z-score of the body mass index determined by the WHO reference ${ }^{4}$ presented a plausible range, with a minimum value of 4.15 and maximum value of 4.74 .

The classification of overweight and obesity is crucial to determine the actual extent of the problem in public health. Therefore, the absolute difference in prevalence identified among the references presents a challenge for the determination of the real burden of overweight and obesity in students in the initial grades of public elementary schools in Rio Branco; as a consequence, it will hamper comparisons among populations and hinder the development of actions for the prevention of overweight and obesity. 


\section{REFERENCES}

1. Monteiro CA, Benicio MHA, Konno SC, Silva ACF, Lima ALL, Conde WL. Causes for the decline in child under-nutrition in Brazil, 1996-2007.

2. Barry MP. Contemporary nutrition transition: determinants of diet and its impact on body composition. Proc Nutr Soc. 2011;70(1):82-91. DOI: http://dx.doi.org/10.1017/S0029665110003903

3. Abreu LC. Obesidade e condições relacionadas à obesidade secundária na interface do crescimento e desenvolvimento. Rev Bras Crescimento Desenv Hum. 2011;21(1):7-10.

4. Onis M, Onyango AW, Borghi E, Siyam A, Nishida C, Siekmann J. Development of a WHO growth for school-aged children and adolescents. Bull World Health Organ. 2007;85(9):660-7. DOI: http://dx.doi. org/10.2471/BLT.07.043497

5. Cole TJ, Bellizzi MC, Flegal KM, Dietz WH. Establising a standart definition for child overweight and obesity worldwide: International survey. BMJ. 2000;320:1240. DOI: http://dx.doi.org/10.1136/bmj.320.7244.1240

6. Conde WL, Monteiro CA. Body mass index cutoff points for evaluation of nutritional status in brazilian children and adolescents. J Pediatr (Rio J). 2006:82(4):266-272. DOI: http://dx.doi.org/10.2223/JPED.1502

7. Dumith SC, Farias Júnior JC. Sobrepeso e obesidade em crianças e adolescentes: comparação de três critérios de classificação baseados no índice de massa corporal. Rev Panam Salud Publica. 2010;28(1):305. DOI: http://dx.doi.org/10.1590/S1020-49892010000700005

8. Leite N, Milano GE, Lopes WA, Tanaka J, Dressler V, Radominski RB. Comparação entre critérios para índice de massa corporal na avaliação nutricional em escolares. Rev Educ Fis. 2008;19(4):557-63. DOI: http://dx.doi.org/10.4025/reveducfis.v19i4.4709

9. Kovalskys I, Rausch Herscovici C, De Gregorio MJ. Nutritional status of school-aged children of Buenos Aires, Argentina: data using three references. J Public Health (Oxf). 2011;33(3):403-11. DOI: http://dx.doi. org/10.1093/pubmed/fdq079

10. Mushtaq MU, Gull S, Mushtaq K, Abdullah HM, Khurshid U, Shahid U, et al. Height, weight and BMI percentiles and nutritional status relative to the international growth references among Pakistani school-aged children. BMC Pediatr. 2012;12:31. DOI: http://dx.doi.org/10.1186/1471-2431-12-31

11. Twells LK, Newhook LA. Obesity prevalence estimates in a Canadian regional population of preschool children using variant growth references. BMC Pediatr. 2011;11:21. DOI: http://dx.doi.org/10.1186/14712431-11-21

12. Petroski EL. Antropometria: técnicas e padronizações. Jundiaí: Fontoura; 2011.

13. Souza OF, Farias ES. Magreza e sobrepeso em escolares de Rio Branco, AC, Brasil. Rev Bras Crescimento Desenvolv Hum. 2011;21(3):878-82. DOI: http://dx.doi.org/10.7322/jhgd.20040

14. Monasta L, Lobstein T, Cole TJ, Vignerová J, Cattaneo A. Defining overweight and obesity in pre-school children: IOTF reference or WHO standard? Obes Rev. 2011;12(4):295-300. DOI: http://dx.doi.org/10.1111/ j.1467-789X.2010.00748.x

15. Pelegrini A, Silva DA, Gaya AC, Petroski EL. Comparison of three criteria for overweight and obesity classification in brazilian adolescents. Nutr J. 2013;12:5. DOI: http://dx.doi.org/10.1186/1475-2891-12-5

16. Landis JR, Koch GG. The measurement of observer agreement for categorical data. Biometrics. 1977;33(1):159-74.

17. Leone C. Human Growth: parameters and reflections about growth references. J Hum Growth Dev. 2014;24(1):7-10.

18. Bezerra IMP, Sorpreso ICE. Concepts and movements in health promotion to guide educational practices. J Hum Growth Dev. 26(1):11-20. Doi: http://dx.doi.org/10.7322/jhgd.113

This article is distributed under the terms of the Creative Commons Attribution 4.0 International License (http://creativecommons.org/licenses/by/4.0/), which permits unrestricted use, distribution, and reproduction in any medium, provided you give appropriate credit to the original author(s) and the source, provide a link to the Creative Commons license, and indicate if changes were made. The Creative Commons Public Domain Dedication waiver (http:// creativecommons.org/publicdomain/zero/1.0/) applies to the data made available in this article, unless otherwise stated.

\section{Resumo:}

Introdução: No diagnóstico do sobrepeso e obesidade pelo índice de massa corporal em crianças e adolescentes existem vários referenciais antropométricos nacionais e internacionais recomendados. Entretanto, há divergência na estimativa de prevalência do sobrepeso e obesidade pelos entre os referenciais.

Objetivo: Identificar a prevalência do sobrepeso e obesidade e examinar a magnitude da concordância entre três referenciais.

Método: Estudo transversal realizado com 975 estudantes das séries iniciais do ensino fundamental. Prevalências do sobrepeso e obesidade foram estimadas conforme recomendações da Organização Mundial de Saúde (OMS), International Obesity Task Force (IOTF) e Conde e Monteiro. O índice de Kappa ponderado foi calculado para avaliar concordância entre três referenciais.

Resultados: As maiores prevalências de sobrepeso e obesidade foram estimadas pelos referenciais de Conde e Monteiro e OMS, respectivamente. De modo geral, o referencial do IOTF revelou magnitude de prevalência inferior aos outros referenciais. A concordância entre os referenciais antropométricos identificados pelo índice de Kappa apresentou amplitude de 0,66 até 0,94.

Conclusão: Apesar da satisfatória concordância entre os três referencias, foram identificados magnitude divergentes de prevalência de sobrepeso e obesidade. Este fato limita a comparação entre populações e dificulta a elaboração de ações de prevenção do sobrepeso e obesidade.

Palavras-chave: prevalência, índice de massa corporal, antropometria, sobrepeso, obesidade, estudantes. 